\title{
ULRICH HAARMANN
}

Rather the injustice of the Turks than the righteousness of the Arabs

Changing ,Ulamā' attitudes towards Mamluk rule in the late fifteenth century 
RATHER THE INJUSTICE OF THE TURKS

THAN THE RIGHTEOUSNESS

\section{OF THE ARABS-CHANGING 'ULAM $\bar{A}$ ' ATTITUDES TOWARDS MAMLUK RULE IN THE LATE FIFTEENTH CENTURY}

1.

The paucity of political writing in Mamluk Egypt and Syria(1) stands in sharp contrast to the exorbitantly rich contemporary historiographical and secretarial literature. The region produced no political theoretician comparable to Ibn Haldūn (d. 808/1406), the great Maghribī immigrant to Cairo, or to the Iranian jurist Fażlallāh b. Rūzbihān Hunğì (d. 927/1521),(2) who-under conditions well comparable to those prevailing in the Mamluk domains -brought al-Gazzālī's theory of the condominium of caliph and sultan up-to-date, $\left({ }^{3}\right)$ postulating the concentration of spiritual

(1) On the genre of political treatises in Mamluk Egypt and Syria cf. Brockelmann, GAL 2II 134-5 [166-8], especially the unpublished writings by Ahmad Țūgān (ca. 880/1475), among them a commentary upon al-Māwardī's al-Aḥkām assulțâniyya for Sultan Qāyitbāy, entitled Manhağ as-sulūk fĩ sīrat al-mulūk, ms Aya Sofya 2905, cf. also $G A L^{2}$ I 386 [483]. On political writing under the late Mamluks see also the remarks by Carl F. Petry, "A Paradox of patronage during the late Mamluk period", Muslim World 73 (1983), 182 and note 1.

(2) Cf. Ulrich Haarmann, "Staat und Religion in Transoxanien im frühen 16. Jahrhundert", ZDMG 124 (1974), 332-69; Ann K. S. Lambton, State and Government in medieval Islam. An introduction to the study of Islamic political theory: the jurists, Oxford 1981, 178-200.

(3) Lambton, op. cit., 112. 
guidance and executive power in the one and single hand of the imām-sulțān. In Hunǧì's case this leader was the Uzbek hăan, who-like the Mamluk rulers-was of Turkish, i.e. non-Quraší, non-Arab stock.

Yet whereas post-Mongol Iran and Central Asia were fertile soil for political speculation, the intellectual life in fifteenth century Egypt and Syria was characterized by a petrified conservatism. The consciousness of having been spared the pagan yoke of the vile Mongol foe produced a sentiment of rigorous fealty to the traditional social and legal norms in their Arab and orthodox garb. Defy illicit innovation in its very inception! - thus one may well formulate the doctrine not only of Ibn Taymiyya, the great religious thinker of early Mamluk times, but of social and legal thought in the Mamluk period at large. The retrograde orientation of Mamluk society impeded the contemporary observers in perceiving the inevitable institutional changes. The de facto disappearance of the caliphate was not made the starting-point for a new theory of government. The old fiction of al-Ġazzālī's time was dragged along. And more so, since Mamluk autocrats themselves, unsure of their title for power, set up a puppet caliph to grant themselves the lacking legitimacy.(4) The radical changes the Mamluk system of government introduced were kept out of systematic speculation, huge as the number of jurists in this very period was. This silence refers both to the nature of the Mamluk ruling caste (were there limits to their political, military and economic power?), and to the consequential relationship between the Mamluk élite, the nās, and the local population to whom they, the 'ulam $\tilde{a}$ ', themselves belonged. $(5)$

Remarks on institutional developments and on the ubiquitous tensions between rulers and ruled are correspondingly scanty. The famous historians of the time give vast and precious,

(4) On the "Abbasid shadow-caliphs see now the authoritative study by Peter M. Holt, "Some observations on the "Abbāsid caliphate of Cairo", BSOAS 47 (1984), 501-7.

(5) The traditional ideal-type pattern opposing omnipotent Mamluks and powerless ra'āya does not seem to stand the test of a careful and differentiated historical analysis. New ideas on this subject will be pivotal in the Princeton $\mathrm{Ph}$. D. thesis by Shaun Marmon on non-military slavery in Mamluk society. I wish to thank Ms Marmon for highly stimulating discussions on issues of common interest during my visit to Princeton in March 1985. 
yet for the most part disconnected details. Mirrors such as Aḥmad Ṭugāan's al-Burhãn fĩ faḍl as-sultận(6) portray the conduct of an idealized ruler. Ibn S̄àin, al-Asadi, and al-Qalqašandī in their respective manuals of statecraft and chancery procedure give a systematic, yet all too often static and-in al-Qalqašandī's case-even anachronistic view of the contemporary social and political order. Sources of whatever type and in whichever combination that help us reconstruct the careers and the behaviour of individuals who stood in this tension-both rulers and subjects-are therefore especially welcome.

\section{2.}

There is e.g. one author who has hitherto been largely ignored although his own vita exemplifies the contradictions of late Burji society. I am thinking of Muhibb ad-Dīn Muḥammad b. Halìl, generally known under his kunya Abū Hāmid and his nisba alQudsī or al-Maqdisī. He was born in Ramla near Jerusalem in $817 / 1414$ or $819 / 1416$ of parents who had emigrated from the eastern Nile delta to Palestine (hence his second nisba alBilbaysi $)\left({ }^{7}\right)$. His father seems to have been a mufti $\left({ }^{8}\right)$. One of his teachers was al-Maqrīzì (d. 845/1442)(9). His main authority seems to have been Tāğ ad-Dīn as-Subkī (d. 771/1370)(10). Abū Hāmid died in Cairo in spring 888/1483.

Abū Hāmid produced a rich scholarly auvre. At least three(11) of his books are preserved. If this author has up till now been

(6) Ms Berlin 5619, cf. GAL ${ }^{2}$ II 135 [167-8].

(7) Cf. as-Sahāwī, aḍ-Daw' al-lāmi', VII, Cairo n.d., 234-7. Ibn Iyās, Badā'i $a z-$ zuhūr, ed. M. Mușțafā, III, Cairo 1383/1963, 200. I was guided to these references by Micheal Cook, "Abũ Ḥāmid al-Qudsĩ (d. 888/1483)", JSS 28 (1983), 85-97, here 92.

(8) Bad̆l an-nașāih aš-šar'iyya fīmā 'alā 's-sultān wa-wulāt al-umūr wa-sā'ir arra'iyya, ms Berlin 5618 (GAL 2II 134 [167]), fol. 19b.

(9) Cf. al-Fadä'il al-bāhira fī mahāàin Miṣr wa'l-Qāhira, ed. K. Muhandis, Cairo 1969 , e.g. 121,$8 ; 124,4 ; 127,12$.

(10) Cf. Badl, 14a.

(11) On him as possible author of ad-Durra al-mudīa fi habar ad-dawla alašrafiyya (= Tārīh al-Malik al-Ašraf Qãyitbãy), cf. Șubḥī Y. Labīb, "Qudsī’s Werk 'Duwal al-Islām aš-Sarīfa al-Bahiyya wa Dikr mā Ẓahara lĩ min Hiikam-Allāh alHafiyya fị Ğalb Ṭāifat al-Atrāk ilā ad-Diyār al-Mișriyya", Der Islam 56 (1979), 117 120, here 118; M. Cook, "Abū Ḥāmid...", 96-7. 
denied the attention he deserves, part of the blame goes to Carl Brockelmann who contrived to attribute his extant three tracts $\left({ }^{12}\right)$ to as many as three different authors in a total of four different entries $\left({ }^{13}\right)$.

Abū Hāmid's first book to be discussed here, al-Fad̄à'il al-bāhira fì mahāasin Miṣr wa'l-Qāhira, is a conventional mufädala, contest, between his two home countries Egypt and Syria. He fervently, often passionately, opts for his new abode, Egypt. The numerous fadā'il Missr, from Egypt's proverbial fertility to the ubiquity of mirabilia both of nature and man-made, should not detract us from his central remark, that Egypt, in his days, has become the heartland of Islam (baydat al-islām), indeed the sole refuge of civilization(14). In the chapter on the few assets Egypt has to share with other countries $\left({ }^{15}\right)$ in past and present he mentions $\left({ }^{16}\right)$ the seat of the caliphate. For him the transfer of Abbasid royalty from Baghdad to Cairo is a well-deserved and natural given.

Abū Hāmid's tendency towards comparing Egypt and Syria becomes palpable also in his second book(17), a remarkable-albeit not always very original-alloy of a mirror-of-sultans work and an exceptionally detailed manual of hisba. The book is entitled, possibly in imitation of similar works by Ibn Rafa (d. 710/1310)(18) or Ğalāl ad-Dīn al-Bulqīnī (d. 824/1421)(19): Baḍl an-nașā'iḥ aš-

(12) I.e. al-Fadā'il al-bāhira; Bad̆l an-nașāiḥ; Duwal al-islām.

(13) GAL ${ }^{2}$ II 42 [52], 132 [164]; S II 40: al-Fadä'il al-bāhira.-GAL ${ }^{2}$ II-; S II 51/2: Duwal al-islām.-GAL ${ }^{2}$ II 134 [167]; S II-: Badll an-nașāih. Cf. also M. Cook, 91 .

(14) See Ulrich Haarmann, "Regional sentiment in medieval Islamic Egypt", BSOAS 43 (1980), 58-9. This book was written in A.H. 871/1466/7, cf. al-Fada' il, 131 line 4 and note $1(389+482=871)$ and the remark by the editor in the introduction page $h \bar{a}$.

(15) al-Fadä'il, 188 ss.

(16) Nr. 13 out of 29.

(17) Badl, 9b: Egypt the most powerful and largest province of Islam; nowhere else does one find so many scholars; 14a: by contrast reproachful remarks on the miserable status of the Egyptian peasantry.

(18) Identical title Bad̆l an-nașā'ih, etc. Cf. GAL ${ }^{2} I I 134$ [166/7]; Brockelmann presents Abū Hāmid's tract as an imitation of Ibn Rafo's work. The exact degree of dependance of Abū Hāmid's Baḍl from Tāğ ad-Dīn as-Subkīs Mu'îd an-ni'am wa-mubìd an-niqam (see below note 21 ) - and possibly Ibn Raf'a's Badl an-nașāih still has to be carefully elaborated.

(19) In Baḍl, 18b-19a, Abū Hạmid quotes al-Bulqīnī's Baḍl an-naṣị̣a fĩ daf alfadiha; a copy also of this work is preserved in a unique Berlin ms, $\mathrm{Nr} .5615$ (cf. $G \dot{A L}{ }^{2}$ II 112/3 [137], title without the first element " $B a d l$ ") and will thus also be available for textual comparison. 
šar iyya fīmā 'alā 's-sultān wa-wulāt al-umūr wa-sā'ir ar-ra'iyya, "ample legal advice for the sultan, for those in command, and for all subjects". It is preserved in a unique Berlin manuscript that was prepared by one of Abū Hāmid's students in Muharram 880 /May 1475, i.e. during the author's lifetime. ${ }^{(20)}$ Much of its contents is taken verbatim from earlier works of a similar genre, notably Tāğ ad-Dīn as-Subkī's $K$. Mu'ìd an-ni'am wa-mubìd anniqam.(21) To my knowledge it has up till now not found any attention. The book was composed three years before al-Fadä'il al-bāhira in 868/1463-4 under the rule of Sultan Hušqadam. Like many other sultans of the late Circassian period Hušqadam impressed contemporary 'ulam $\bar{a}$ ' favorably with his personal piety, his leanings towards mysticism, $\left.{ }^{(22}\right)$ and his tenacity in the enforcement of the šarì'a. Abū Hāmid finds complimentary words about his sovereign. "He discontinued the heinous practice (al-mafsada al-'azima) of employing dimmis in matters that concerned only Muslims, thus taking resort to the just kings (almulük al-'ädilīn)"'(23). Justice ('adl) here clearly denotes the consequent execution of the prescriptions of the sari ${ }^{\circ} a$ by those in power.

Yet those ordained and exclusively qualified to guard the Sacred Law are the 'ulamā'/fuqahä' to whose ranks Abū Hāmid himself belongs. In his own words: "They are the fätiha to all bliss in this and in the other world" $\left({ }^{24}\right)$. Quoting an older authority he extols the privileged status of his class within the community of believers: "We are the salt of the country and heal the rotten affairs of the populace. And when the salt itself is rotten, who is there to heal it?"'(25)

(20) Colophon of Badl, $59 \mathrm{~b}$.

(21) Ed. David M. Myhrman, London 1908 (reprint AMS Press New York, 1978). See $G A L^{2}$ II 90 [110], S II 106 with reference to V. Zetterstéen's critical remarks on this edition. I have also used the German (shortened) translation by Oskar Rescher (Osman Reșer): Tâg eddîn Es Subki's Mu'îd en-ni'am wa mubîd en-niqam. Über die moralischen Pfichten der verschiedenen islamischen Bevölkerungsklassen, Konstantinopel 1925, 'Osnabrück 1980 (=vol. II/2 of Rescher's Gesammelte Werke).

(22) Quoting as-Subkī, Mu'ĩd, 171 line 3 (= Rescher 121), Abū Hāmid expresses his high regard for the Sūfis (Badl, 22b).

(23) Badl, 9a-b.

(24) Badl, 10b.

(25) Bad̆l, 31a. The source given is Kitāb al-Imām Abū 'l-Qāsim ad-Damrì (unidentified). References to the 'Abbāsid caliph al-Mustaẓhir give his rule 
Following Ibn Taymiyya's social model he concentrates on one prominent theme in his treatise: the polarization between 'ulamä' and umara '. The 'ulama', the divinely chosen guardians of the just order are, owing to the overbearance of the Mamluk officers, deprived of their legitimate rights and dignity $\left({ }^{26}\right)$. Money accruing from the entire community of believers is squandered on luxurious robes, saddles, horse trappings, gilded inkwells, and, most abominably, on beautiful young Mamluks, slave girls and singers. $\left({ }^{27}\right)$ The 'ulamā' stand by empty-handed. In the good old days of the just imāms (a'immat al-'adl) the barid was used for important affairs, i.e. also, as Abū Hāmid and his source seem to imply, in order to grant merited 'ulamä' a decent means of transportation; in our decadent times, however, so our authors complain, it has become the vehicle for handsome youths and concubines ${ }^{(28)}$. Hypocritically - so Abū Hāmid goes on complaining-hundreds and hundreds of pious endowments are erected by the amirs with funds extracted from the raiyya. Yet not for God's sake, but only to perpetuate the wordly fame of the donor. $\left({ }^{29}\right)$ On journeys and campaigns expensive doctors are taken along, but no faqih, although he would cost the amīr only one fifth of the amount to be showered on the physician, and although the concern for one's body should only come second to concern for salvation. $\left({ }^{30}\right)$ The weapon of our irascible author, blunt as it must have been, is the threat with ultimate retribution. Will these transgressors not eventually receive their just penalty, he muses. There is e.g. the story of the selfrighteous drunken amir who-unlike an equally inebriated 'älimdoes not repent and does not solicit his just punishment, but rather vexes his infelicitous learned boon-companion, until at last, so Tāğ

(487/1094-514/1118) as terminus post quem. On the margin of our ms. there is added: "some authors say: You scholars on earth, salt of the country! Who shall heal the salt when the salt is rotten?".

(26) Badl, 16b, cf. Mu'id, 67, 4-6; 68, 12ff. (= Rescher, 34-36).

(27) Bad̆l, 7b; 10a (=Mu'ìd, 28, 8-12; Rescher, 2); 11a (=Mu'ĩd, 30, 1-3; Rescher, 3); 17a (=Mu'id, 69,9ff; Rescher, 36-9).

(28) Badl, 14b, following $M u^{\circ} i d, 46,7-11$ (Rescher, 17). On the muqaddam almamälik as chaperone of the beardless Royal Mamluks see Badl, 15a (=Mu'id, 56,6-7; Rescher, 24).

(29) Badl, 11a (see also the brief remarks in $M u^{\prime} i d, 32,11-12$; Rescher, 5-6).

(30) Badl, 12a (=Mu'ìd, 34, 7-11; Rescher, 7). 
ad-Dīn as-Subkī and Abū Hāmid state with relief, "God destroyed the sinner after only a few days"'.( $\left.{ }^{31}\right)$

The umarā' leave the 'ulam $\bar{a}$ ' hungry by the side, "piling one plight upon the other" (balā' 'alā balä').( $\left.{ }^{32}\right)$ Even the lowliest Mamluk private earns more than the most respected scholar.( $\left.{ }^{33}\right)$ And to underscore the injustice of such a distribution of wealth he brags on behalf of his fellow 'ulamä': Do not the Mamluks, these despicable slaves, $\left.{ }^{(34}\right)$ owe abundance and might ultimately to us scholars? For we are the ones who teach the uncivilized Mamluk youngster the basic commandments of Islam and the two phrases of the sahäda, thus opening for them the gates of advancement to high and highest rank? $\left({ }^{35}\right)$

Only sometimes Abũ Hāmid seems to become aware of the lack of realism in the scenario he depicts. Well, Mamluks and nonMamluks are all human creatures and as such not immaculate (ma șum). $\left({ }^{36}\right)$ The sultans who are to be the shephards of the ra'iyya and the protectors of the 'ulama $\bar{a}^{\prime}\left({ }^{37}\right)$ cannot be measured against the just kings of the past. $\left.{ }^{(38}\right)$ In a long special chapter on the sultans that is for the most part independent from earlier sources $\left({ }^{39}\right)$ Abū Hāmid treats the rulers more leniently than the officers. The sultans in our days cannot be expected to devote all their energies to the administration of right and justice.( $\left.{ }^{40}\right)$ It would be truly preposterous to liken the mulk at-Turk to the kingdom of Muhammad's Companions.(41)

Nevertheless some features in the present political and social order are to be reformed by all means. Highly immoral inno-

(31) Badl, 16b (=Mu'id, 68,8-11; Rescher 35-6). On the reprehensibility of drunkenness see also Badl, 15a (=Mu'id, 53,6; Rescher, 22), chapter on the sāqi. Often Mamluk pages killed their masters, cf. Bad̆l, 15a (=Mu'id, 54, 8-10; Rescher, 22).

(32) Badl, 10a-b (=Mu'ìd, 29, 2-6; Rescher, 2).

(33) Baḍl, 10b (lā yaṣilu ilā miqdār rizq aqall mamlūk lahum aw 'abd aw ğulām).

(34) Cf. chapter I/§ XXII of Badll on the ağnād, soldiers, 17a-b (= Mu'id, 74-5; Rescher, 41-2).

(35) Bad̆l,10b (fa-innahū awwal man yulqinuhum al-islām wa-kalimatay aššahāda).

(36) Badl, 16b (differing from $M u ' i d, 67,9)$.

(37) Badl, 10a (= Mu'id, 28, 13-29, 10; Rescher, 2-3).

(38) Badll, 11a (=Mu'id, 32,2-5; Rescher, 5).

(39) Badl, 4a-17b.

(40) Badl, 11b.

(41) Badl, 14b (=Mu'id, 53, 7-8; Rescher, 21). 
vations such as the office of page $(s \bar{a} q \bar{\imath})\left({ }^{42}\right)$ and of basin-bearer (țištdār) (43) should be abolished. Is it not the supreme duty of the ruler to keep innovations and heretic-i.e. Sî̀-tendencies (ahwä') with particular conscientiousness away from the orthodox Muslim populace?(44) Diligently Abū Hāmid quotes from Ibn Taymiyya's guidelines of just rule, as-Siyāsa aš-šar iyya fī iṣlāh ar-rāei wa'rra'iyya.(45) Should not the secretaries (kâtib as-sirr), $\left.{ }^{46}\right)$ the major domus (ustādār)( $\left.{ }^{47}\right)$ and the viziers $\left({ }^{48}\right)$ with their constant and tight ties to the ra'iyya again and again be admonished to make their protection their first commandment? Is not the inspector of the army (nāzir al-ğayš) in his true and basic function a nāzir al-yatīm, a warden of orphans? $\left.{ }^{49}\right)$

The one important Mamluk institution in which Abū Hāmid's (and his predecessor's Tāğ ad-Dīn as-Subkī's) ideal views and political reality clash with particular violence is the huğ $\bar{u} b i y y a$, the office of the chamberlain. In Mamluk days, so Abū Hāmid regrets, this important office has long since lost its former and lofty functions. ${ }^{50}$ ) It has become the frame for an independent Turkish judiciary, set up for internal Mamluk litigation. We encounter similar processes of a bifurcated legal administration in all Islamic domains that were influenced by the Mongol yāsa. For our author there is no need for the hăğib, this "judge and arbiter of the Turks",($\left.{ }^{51}\right)$ as he puts it. This siyassa is not only redundant, it is rather outright dangerous because it feeds the illusion that common sense and customary law can help regulating life and can form an alternative to the sar $\bar{c}^{-} a$. In his chapter on the customs of the bedouins of the Arabian peninsula "many of whom marry a woman without a legal contract... and withhold from daughters their Koranic share in an inheritance", this same apprehension is articulated.(52) There is no such thing as a "law of the

(42) Ibidem.

(43) Badl, 43a (=Mu'íd, 197, 9-10; Rescher, 145).

(44) E.g. Badl, 12b (=Mu'id, 35, 6; Rescher, 8).

(45) E.g. Bad $1,6 \mathrm{~b}$.

(46) Badl, 13b (=Mu îd, 43-4; Rescher, 15).

(47) Badll, 13a (=Mu'id, 39-40; Rescher, 11).

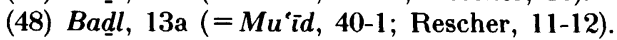

(49) Badl, 14a (=Mu'id, 48, 10; Rescher, 19).

(50) Badll, 15a-b (= Mu'id, 57, 1-60,3; Rescher, 24-27).

(51) Badl, 15b, cf. Mu'id, 57,5-6, omitting the crucial term "arbiter", "arbitrating".

(52) Badll, 17b (=Mu'id, 75-6; Rescher, 42-3). 
bureaucracy" (šar ad-dīwān),( $\left.{ }^{53}\right)$ he insists, there is only the one Law of God.

Yet our memorialist has also some bitter advice for his compeers, especially the muftis with their enviable influence on public affairs: $\left({ }^{54}\right)$ Do not give away your honor, resist the temptations of bribery and corruption, do not make yourselves contemptible ingratiating yourselves with the sultans and amirs. The latter will only despise you if you solicit status and lucrative appointment (at-taraddud ilā abwāb as-salāțīn wa'l-umarā'... wahubb al-ğāh wa'l-manāșib). And if you try to justify such a behaviour to yourself and to others-he continues, following as-Subkī's text-, so you only lie to yourself and risk forfeiting the rewards of the other world.(55) If you are looking for a living, he closes, be honest, your income as a scholar is sufficient. If you are, however, out for luxury (duny $\bar{a})$, then better change your job and become a lowly clerk in the diwañn or in the army; you will fare better! $\left({ }^{56}\right)$

3.

Twelve years later, during Qāyitbāy's sultanate, Abū Hāmid writes his third work and dedicates it to a famous Mamluk general. $\left({ }^{57}\right)$ The title of the treatise is odd, not only because of its cumbersome length and the reference to the first person, but in particular because of its message: Duwal al-islām aš-šarîfa albahiyya wa-dikr mã zahara lì min hikam allāh al-hafiyya fí ğalb țā'ifat al-atrāk ilä 'd-diyār al-mișriyya, "on the noble and radiant Islamic states, as well as on God's hidden blessings - as I became aware-of guiding the people of the Turks to the Egyptian lands".(58)

(53) Bad̆l, 14a (chapter on the nāzir al-ğayš) (=Mu'îd, 49, 9; Rescher, 19).

(54) Badl, 20b, cf. Mu ìd, 145-151 (considerably more detailed than Badl); Rescher, 97-103.

(55) Badl, 20a (=Mu'ìd, 96, 8-97, 8; Rescher, 60).

(56) Badll, 20b (= Mu id , 101,11-15; Rescher, 63).

(57) According to Brockelmann GAL S II 51/2: al-Malik al-Ašraf Yašbak adDawādār. On this general who died a victime of the Aq Qoyunlu in 885/1480 cf. Barbara Flemming, "Šerîf, Sultan Gavrī und die 'Perser',, Der Islam 45 (1969), 81-93, here 87-89. Ibn Ağā's Arabic Rihlat (tārīh) al-Amīr Yašbak az-Zāhirī is now available in print (ed. 'Abd al-Qādir Aḥmad Țulaymāt, Cairo, 1973-4). On my suggestion Karin Klingbeil/Freiburg prepares a German translation of this text.

(58) Cf. Șubhii Y. Labīb's article (see above note 11). The late Professor Labìb has prepared an edition of this text for Bibliotheca Islamica. 
In this work Abū Hāmid, as the title already indicates, radically changes his position towards Turks and Arabs, Mamluks and 'ulama'. Blessed by the gracious gift of conversion to Islam and instructed by selected fuqahä', these Mamluk Turks devote their energies and their lives to the defence of the community of believers, "the family and nation of Islam". $\left({ }^{59}\right)$ They cheerfully shoulder the burden of the Holy War, thus exonerating the unmartial people of Egypt-an age-old topos!-from complying with this fard al-kifãya themselves. Rightfully they in return harvest the riches of the country. It is the Turks who protect the helpless subjects against brigandry and looting by highwaymen and unruly bedouins. In the cities they guarantee prosperity, tranquillity and peace. With their valour they instill awe among all those who might otherwise be tempted to infringe upon the rights of the people. Quite apart from their physical beauty most Mamluks are imbued with clemency, audacity and unselfishness. They afford protection (himã). Acquaintance with a Turk, so Abū Hāmid maintains, gives all Egyptians, scholars, peasants or proletarians (zu'r), status, pride, and security. Even if the Mamluks relish their power and "feel like kings", $\left({ }^{60}\right)$ and even if the newcomers from the steppes sometimes vex and haunt the Egyptian natives indiscriminately, i.e. even 'ulamã', so they do this only, he awkwardly rationalizes, $\left({ }^{61}\right)$ because their Arab victims deserve such a treatment for misdemeanour, curruption and crime and are thus most conveniently freed from a similar or even harsher punishment in the Hereafter!

We now face a most puzzling situation. The rôles of villain and hero are completely reversed. You will remember: Whereas Abū Hàmid (emulating 'ulamā' of the past) in 1463/4 in Badl an-nașầ'ih contrasts the justice and humility of the ill-treated and neglected 'ulam $\bar{a}$ ', the "salt of the country", with the haughty airs and blatant tyranny of the Mamluk amirs, he heaps now, twelve years later, all blame on the intolerably self-righteous and pernicious 'ulam $\bar{a}$ '. His reservations against the Mamluk autocracy have dwindled into token criticism. He reviles the selfish arrogance, envy and heartlessness of the 'ulamé' in contrast to their Turkish

(59) Labīb, 120, quoting Abū Ḥāmid: "sie [i.e. the Mamluks] opfern sich für den Sieg der Familie und des Volkes des Islams".

(60) Labīb, 120: "obwohl er [i.e. Abū Hāmid] zugeben mußte, daß sich der Mamluk im 15. Jahrhundert 'wie ein König fühlte'...".

(61) Labīb, 119. 
overlords. It is the latter whom he now elates as the "salt of Egypt".(62) Sic tempora mutantur. Certainly some of the central themes of Badl an-nașä'ih remain valid, such as the superior obligation of those in command to apply justice and to grant protection to the raiyya, yet blame now goes to the other side. Epitomizing his new social ideology he spitefully quotes the popular slogan: zulm at-turk wa-lā 'adl al-'arab, "rather the injustice of the Turks than the righteousness-or more to the point: self-righteousness - of the Arabs". One could say more freely and a fortiori: "The most tyrannical Mamluk is preferable to even the justest Arab compatriot".(63)

The last element in Abū Hāmid's saying is important. It is not at all the discovery of Mamluk qualities, that had hitherto remained unappreciated, that turned his former social model upside down. Rather it was the violent thrust of his new hatred against his comrades in the judiciary and in academe. Abu Hāmid is no longer balanced. The figures he presents in connection with the Mamluk army $\left({ }^{64}\right)$ and their recruiting policies, e.g., seem to me to be vastly exaggerated. His readiness to acquiesce in Mamluk mismanagement (an undeniable reality in fifteenth century Egypt he himself had attacked so vituperatively before) speaks for itself. $\mathrm{He}$ is driven by the desire to retaliate against his fellow 'ulam $\bar{a}$ ', to take revenge-even at the price of the very ingratiation with the amirs which he himself had singled out as a particular abuse.

4.

Yet whence this desire for revenge? We are lucky enough to find a clue for Abū Hāmid's erratic change of mind in contemporary prosopographies. As-Sahāwī, who is notorious for his unfriend-

(62) Ibidem.

(63) Labīb, 118. Cf. also Ignaz Goldziher, Muhammedanische Studien, Halle an der Saale, I, 1889-90, 271.

(64) Labib, 117 (uncritically). See David Ayalon's painstaking research on the figures of Royal Mamluks imported by the individual Bahrī/Burğì sultans in his "Studies on the structure of the Mamluk army", BSOAS 15 (1953), 222-8. He maintains (referring to Abū Hāmid's teacher al-Maqrīzī) that al-Malik an-Nāṣir Muhammad b. Qalāwūn did not import-as Abū Ḥāmid claims-100.000 Mamluks, but at most some 12.000 ! 
ly comments about colleagues, devotes a lengthy tarğama to our emotionally instable hero.( $\left.{ }^{65}\right)$ Abū Hāmid was pious, industrious and diligent-as-Sahāwī maintains - yet simply not intelligent and perceptive enough to stand up to the tough scholarly competition of his time.(66) People mocked at his slow mind and his fussiness. And yet more destructive to his emotional balance must have been the disillusioning experience Abū Hāmid had with a teacher whom he adored and whose baraka and pure soul he made vociferously responsible for the gifts reserved for himself in this and in the other world and for the utmost "love and respect" (al-mahabba wa'l-qabūl) he believed to enjoy among the contemporary 'ulamá'. Some day he learned that not only his, as he thought, jealous colleagues, but even his idealized pir himself despised him. He was thrust into an abyss of despair. The former euphoria of being loved and accepted turned into abject depression (al-ḩumūd wa'l-humūl).( $\left.{ }^{67}\right)$.

Ibn Iyās quotes two lines of poetry which one of Abū Hāmid's mean adversaries passed to him in public: "Abū Hāmid, your fame is widespread for your numerous writings and compilations in crafts in which you are unrivalled / Your learnedness is unique, no one equals you in this country". Abū Hāmid blissfully read the verses, convinced that they were written in good intent. "He did not grasp the plot laid against him in the two lines". Proudly he quoted them in his own works, passed them on to others-thus making a complete fool of himself.( $\left.{ }^{68}\right)$

At some time between 1463 and 1475 Abū Hāmid must have wakened up from his stupor of self-aggrandizement, realizing the cynicism and contempt of his environment. His encomium of the Mamluks and his verdict on the unbearably arrogant 'ulam $\bar{a}$ ' now suddenly loses its enigma and becomes plausible. Michael Cook who has helped us in the correct attribution of the first work, alFaḍa'il al-bāhira, to Abū Hāmid's authorship and dug up the two biographical notices, is too harsh when labelling him but "rather undistinguished" $\left.{ }^{69}\right)$ and stressing his "outstanding stupidity".( ${ }^{70}$ It would in my view be more equitable to speak of

(65) ad-Daw' al-lāmi, VII, 234-7, nr. 575.

(66) Loc. cit. 237, 1-7.

(67) Loc. cit. 237, 8-13.

(68) Ibn Iyās, Badā'i az-zuhūr, III, 200, lines 1-9.

(69) "Abū Ḥāmid al-Qudsī”, JSS 28 (1983), 85.

(70) Loc. cit. 92. 
Abū Hāmid's stunning naiveté and psychic fragility. And it is the very trial the sensitive, slow and vulnerable Abū Hāmid suffered from his haughty foes, and the reflection of this mihna in his own writing that turn him into such an unusually personal and lively and at the same time valuable witness to Egyptian scholarly mentality in the late Burji period. It is hardly by sheer coincidence that Abū Hāmid received the idea of writing his book on God's mercy of sending the Turks to Egypt in a dream.( $\left.{ }^{71}\right)$ Haunted by his merciless enemies, so I imagine, he desperately turned to istiharara $\left({ }^{72}\right)$ to find a way out of his deadlocked emotional misery.

5.

I do not intend to turn this essay into a mere recording of the plight of a late medieval Arab historian. Yet there are elements in Abū Hāmid's personal development that are relevant beyond the narrow scope of his individual biography. His vacillation between denigration and adoration of the Mamluk governing caste is certainly much more than a mere function of the status of his patron-in the case of Duwal al-isläm a Mamluk grandee. It reflects the profound instability of the relations between the firmly corporate Mamluk élite, on the one hand, and the 'ulam $\bar{a}$ ' class, on the other.

And who were the 'ulamā' to begin with? Not only we today who love to indulge in 'ulemalogy - to use Roy Mottahedeh's phrase $\left({ }^{\mathbf{7 3}}\right)$ - are at odds. In the footsteps of Tăğ ad-Dìn as-Subkī Abū Hāmid shared this insecurity. In his cautious definition the 'ulam $\vec{a}$ ' "consist of many groups such as Koran commentators, traditionists, jurists, specialists on legal dogmatics, theologians, grammarians and the like, and each group is again ramified into

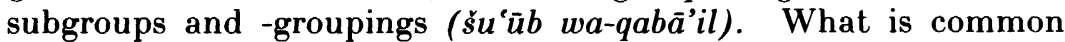

(71) Labīb, 120 (night of 23 Sawwāl 880/19 February 1476).

(72) On istihâra, soliciting God's advice in a dream, as a popular stratagem (not only in Mamluk Egypt) for people shunning grave decisions, cf. Barbara Langner, Untersuchungen zur historischen Volkskunde Ägyptens nach mamlukischen Quellen, Berlin 1983, 81-5.

(73) Review of R. W. Bulliet, The patricians of Nishapur, in: JAOS 95 (1975), 491a-495a, here 495a. 
to all of them" - so he continues - "is their duty of guiding the Muslims, of complying with the demand for legal opinion, of counseling the students and of granting knowledge to all those who seek it".( $\left.{ }^{74}\right)$

The research by Ira Lapidus $\left({ }^{75}\right)$ and, more recently, Carl Petry $\left({ }^{76}\right)$ has impressively demonstrated the powerful and often quite sophisticated mechanisms of control the Mamluk rulers employed against the local subjects, among them the 'ulamā'. Though I am convinced that the boundlessness of Mamluk despotism and correspondingly the despondent helplessness of the ra'iyya have been overestimated for a variety of reasons, $\left({ }^{77}\right)$ there remains the Mamluk power potential. The Mamluks were the sole political and military masters and monopolized the economic resources of the empire. In their search for sanctions against the injustice of the Mamluk amirs, the 'ulamā'-as we have seen-had to turn to the other world. In the dunyā they could not realistically discern any chance for just retribution. Abū Hāmid's servile eulogies on the merits of the Mamluks stress this hopeless inferiority even better than his conventional critique of the unjust yet paramount ruler twelve years earlier.

6.

One factor in this ambivalent attitude of Abū Hāmid in particular and of contemporary 'ulamä' in general vis-à-vis their political masters should be given special attention: the alienness, the foreignness of the Mamluk Turks. In Abū Hāmid's quotation "rather the injustice of the Turks than the righteousness of the Arabs" this ethnic tension is clearly perceptible. On the one hand the proverbial bravery of the Turkish Mamluks (an old stereotype going back to al-Ğăhiz and Ibn Hassūl who both served Turkish masters) $\left({ }^{78}\right)$ who sacrificed their lives for a religion, a civilization,

(74) Badl, 20a (=Mu'īd, 94, 5-8; Rescher, 57).

(75) Muslim Cities in the later Middle Ages, Cambridge, Mass. 1967.

(76) The Civilian Elite of Cairo in the Later Middle Ages, Princeton 1981.

(77) Their rigorous models of Mamluk society cannot claim overall validity. There were intrinsic limitations to Mamluk autocracy known to both the ruling caste and the ra'iyya. See my review of Petry (note 76) in: BSOAS 47 (1984), 133a-135a, especially 134b-135a.

(78) A survey of this sensitive subject is attempted in my paper: "Ideology 
and a people originally alien to them. Let us recall Ibn Haldūn's phrase of the "blessing of the status of slavery" $\left({ }^{79}\right)$ and the numerous comments on the coincidence that the Mongols, the most deadly danger that ever arose to Sunni Islam in the Middle Ages, were vanquished by their own kind, the Mamluks from the Eurasian steppes.( $\left.{ }^{80}\right)$ The himma turkiyya, Turkish valour and endurance, is invoked.(81) Abū Hāmid's latest book appears to be a mine of apophthegms and comments on Turkish martial and moral virtues.

Yet on the other hand there is also an inveterate anti-Turkish sentiment. Also this feeling has a venerable tradition going back to ninth century Iraq, $\left.{ }^{82}\right)$ and also here Abū Hãmid serves as a crown witness. In his mirror-of-sultans he does not conceal his reservations against the ruling foreign race. If a simple Turk ('ämmi turki) cannot speak the language of the country and thus cannot understand the ahl ad-dikr, the 'ulamä', so he says (again citing Tāğ ad-Dīn as-Subkī), he had better keep his hand away from public office. $\left({ }^{83}\right)$ As already mentioned he arrogantly dismisses the Turkish judiciary as an illicit folly and brings the mulk at-Turk condescendingly in contrast to the glorious days of the Orthodox caliphate. Other authors shared this prejudice, notably as-Sahāwi who polemicized not only against colleagues such as Abū Hāmid or aș-Șayrafī al-Ğawharī(84) whom he charges of lacking scholarly acumen, but also against his teacher Ibn

and history, identity and alterity: The Arab image of the Turk from the "Abbasids to modern Egypt", IJMES 20 (1988), 175-96.

(79) On Ibn Haldūn's esteem for the Mamluk achievement see now Donald P. Little, "Religion under the Mamluks", Muslim World 73 (1983), 165-6.

(80) Abū S̄āma, aḍ-Dayl 'alā 'r-rawḍatayn. Tarāḡim al-qarnayn as-sādis wa's-sā bi $i^{\circ}$ ed. Z. al-Kawtarī, ${ }^{2}$ Beirut 1974, 208. See also Max Meyerhof and Joseph Schacht, The Theologus Autodidactus of Ibn al-Nafis, Oxford 1968, 82, Excursus G.

(81) 'Izz ad-Dīn b. Š̉ddād, Tārīh al-Malik az-Zāhir (=ar-Rawd az-zähir fí sīrat al-Malik az̧-Ẓāhir), ed. Aḥmad Huțayț, Wiesbaden 1403/1983, 120, line 13 (reference is to Baybars' $I$. son and successor as-Saîd Berke Qān).

(82) Cf. e.g. Ibn Lankak al-Bașrī (d. 300/912-3) and his anti-Turkish poem quoted by aț-Taaāibī, Yatimat ad-dahr, II, [Beirut] 1399/1979, 348, lines -4ss.; see also Goldziher, Muhammedanische Studien, I, 152.

(83) Badl, 15b (chapter on the chamberlain) (=Mu'id, 59, 7-60, 1; Rescher, 26-7).

(84) Daw', V, 217-9; cf. Haarmann, "Auflösung und Bewahrung der klassischen Formen der arabischen Geschichtsschreibung zur Zeit der Mamluken", ZDMG 121 (1971), 60. 
Tagirībirdī, a man who understood himself quite admirably as a cultural interpreter between Arabs and Turks. $\left({ }^{85}\right)$

Superstition is, much to the wrath of more differentiating observers, labelled a prototypical Turkish quality against which the Arabs appear to be immune. $\left({ }^{86}\right)$ Mamluks and their retinue were at least in certain attested cases forbidden to enter the premises of certain madrasas, $\left({ }^{87}\right)$ leave alone join them. And the rich and variegated religious and literary culture at the Mamluk court in the Circassian period both in the Turkish, yet also in the Persian and Arabic languages, was simply ignored by local Arab chroniclers. $\left.{ }^{88}\right)$ It is not unlikely that this suppression of important features of Mamluk lore was deliberate. Much to the regret of modern historians these xenophobic 'ulamā' (on whose monopoly of information we all depend) seem to have followed the strategy of passing over in silence what in their view was not to be: Turkish fighters and rulers were acceptable, even indispensable, and this had been the state of affairs for a long time. Yet granting these foreign barbarians parity also in their lofty proper domains, the worlds of learning and of guardianship of the Sacred Law, this was obviously felt to be too heavy a demand upon themselves.

(85) William Popper, "Sakhāwī's Criticism of Ibn Taghrī Birdī”, Studi orientalistici in onore di Giorgio Levi della Vida, II, Rome 1956, 388.

(86) Cf. U. Haarmann, "Alțun Hān und Čngiz Hुān bei den ägyptischen Mamluken", Der Islam 51 (1974), 32 and note 159.

(87) Cf. Felicitas Jaritz, "Auszüge aus der Stiftungsurkunde des Sultans Barqūq", in: S. L. Mostafa, Madrasa, Hānqāh und Mausoleum des Barqūq in Kairo, Glückstadt 1982, 135 and 162 , line 1010. See also the comments by U. Haarmann, "Mamluk endowment deeds as a source for the history of education in late medieval Egypt", al-Abhath/American University of Beirut 28 (1980), 38.

(88) On this neglected subject see the contributions by Annemarie Schimmel, "Sufismus und Heiligenverehrung im spätmittelalterlichen Ägypten", Festschrift Werner Caskel, ed. E. Gräf, Leiden 1968, 274-88, especially 274-5; eadem, "Some glimpses of the religious life in Egypt during the later Mamluk period", Islamic Studies 7 (1965), 353-92. Barbara Fleming, "Serîf, Sultan Gavrī und die 'Perser', (see above note 57); eadem, "Literary activities in Mamluk halls and barracks", Studies in Memory of Gaston Wiet, ed. M. Rosen-Ayalon, Jerusalem 1977, 249-60; eadem, "Aus den Nachtgesprächen Sultan Gaurīs", Folia Rara, Verzeichnis der orientalischen Handschriften in Deutschland, Supplementband 19, Wiesbaden 1976, 22-28; eadem, "Zum Stand der mamluk-türkischen Forschung”, ZDMG. Supplementband II, 2. XIX. Deutscher Orientalistentag, Wiesbaden 1977, 1156-64. Janos Eckmann, “Die kiptschakische Literatur", Philologiae Turcicae Fundamenta, II, Wiesbaden 1965, 299-300. Ulrich Haarmann, "Arabic in speech, Turkish in lineage: Mamluks and their sons in the intellectual life of fourteenthcentury Egypt and Syria", JSS 33 (1988), 81-114. 
So the gulf widened between the two elites, ulü 'l-amr, the umara ' and the 'ulamä', to employ Ibn Taymiyya's and Abū Hāmid's words, who were jointly held responsible for the wellbeing of the populace. ${ }^{89}$ ) For the sake of clarity one may even argue (thus neglecting the indubitable existence of institutions and personalities mediating between Arabs and Turks, locals and aliens, ruled and $\operatorname{ruler}\left({ }^{90}\right)$ ): Between the fortified trenches these two leading groups, Mamluk officers and scholars, had drawn one could find all those dismal individuals and subgroups who for one or another reason were evicted or alienated from their proper Mamluk or 'ulam $\bar{a}$ ' background. There are on the one hand the sons of Mamluks who by virtue of their Muslim birth had forfeited the privileges of their fathers and for the most part seem to have been anything but welcome in the Arab scholarly circles $\left({ }^{91}\right)$ unless they were ready to make a total break with their Turkish past. But in this "no-man's land" between two rather selfcontained worlds we encounter also our tragic hero Abū Hāmid. His ideals - not the least of justice and equity-collapsed when his compeers, the alleged guardians of "adl, treated him so ignominiously. In this disposition of despair and hatred the awesome and inapproachable Mamluk amīrs, Abū Hāmid's previous epitome of unbridled despotism, appear in a strangely mellow light.

\section{Ulrich HaARmann (Freiburg, F.R.G.)}

(89) Baḍl, 11b: ulū 'l-amr șinfāni al-umarā' wa'l-'ulamā'.

(90) One should remember the historians Ibn Taginibirdī or al-Aynī. The latter wrote both in Arabic and Turkish, was courtier (trying to belittle the ethnic tension between Turkish and Circassian Mamluks) and muhtasib/'älim alike. Pertinent comments on this subject are to be expected in the thesis of Shaun Marmon (see above note 5).

(91) See D. Ayalon, "Studies on the structure of the Mamluk army", II, BSOAS 15 (1953), 456-8; U. Haarmann, "Arabic in speech..." (see note 88); idem, "The sons of Mamluks as fief-holders in late medieval Egypt", Land Tenure and Social Transformation in the Middle East, ed. T. Khalidi, Beirut: American University, 1984, 141-5. 